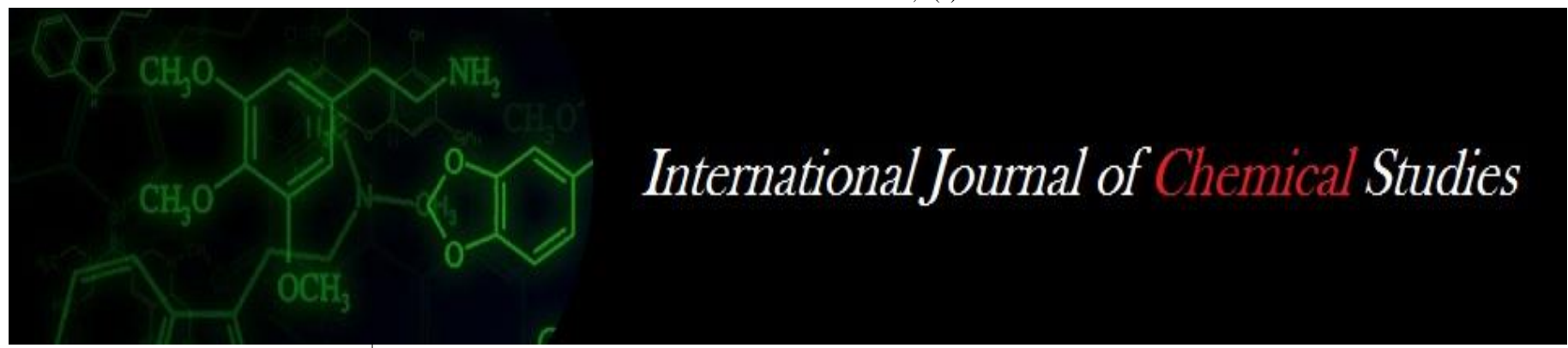

P-ISSN: 2349-8528

E-ISSN: 2321-4902

IJCS 2020; 8(1): 1363-1365

(C) 2020 IJCS

Received: 13-11-2019

Accepted: 15-12-2019

Abhishek Naik S

Department of Agricultural

Extension, UAS, GKVK,

Bengaluru, Karnataka, India

SV Suresha

Department of Agricultural

Extension, UAS, GKVK,

Bengaluru, Karnataka, India

Corresponding Author:

SV Suresha

Department of Agricultural

Extension, UAS, GKVK,

Bengaluru, Karnataka, India

\section{Differences in performance of pomegranate growers under public and private extension services}

\author{
Abhishek Naik S and SV Suresha
}

DOI: $\underline{\text { https://doi.org/10.22271/chemi.2020.v8.i1s.8443 }}$

\begin{abstract}
The Pomegranate is cultivated as a commercial crop because of its high income generating capacity. The pomegranate needs a critical care at the production level and it enhances the need of consultancy service for the production. Hence, there are number of Private people working as consultants along with public extension personnel. The affordability of the growers to pay is a key factor for private extension in the area. The study was conducted in Hiriyuru, Chitradurga and Challakere taluks of Chitradurga district with a total sample size of 120 comprising 60 growers each under public extension and private extension systems. The "Ex-post fact" research design was used in the study. The 40 per cent of the growers were under medium adoption category in public extension services and under private extension service 40 per cent growers were found in high adoption category. The growers who were availed public extension services belonged to medium income category $(43.33 \%)$. Whereas 45 per cent of growers from private extension service fall under high income category. The Benefit to cost ratio was highest in Challakere taluk (3.47) in case of private extension and in Public Extension the highest return was found in Hiriyuru (3.05). The results indicated that the farmers under private extension services obtained higher income by adoption of improved practices. This may be attributed to the facts that the private extension offer recent and competent technological information including marketing services on payment basis.
\end{abstract}

Keywords: Performance, adoption, income, cost of cultivation and B: C ratio

\section{Introduction}

Pomegranate belongs to the Punicaceae family is a very popular sub- tropical fruit, native to Persia (Iran) and is one of the commercially important fruit crops of India (Holland et al., 2009). The edible part (aril) of the fruit is consumed as fresh arils or as processed products such as jams, jellies, wine, and beverages (Aarabi et al., 2008). Scientific evidence has linked increasing consumption of pomegranate fruit to improved human health as a result of active phenolic compounds which have potent pharmacological activities, including, antioxidant, anti-mutagenic, anti-hypertension, anti-inflammatory activities (anchule.,2000) ${ }^{[1]}$.

At the global level, India is the world's largest producer of pomegranates, followed by Iran. Karnataka state produced138.5 million tons of fruits every year. The cultivation of pomegranate for commercial production requires scientific know how since it demands high investment. In the absence of proper extension guidance, the farmers may suffer with huge losses. The National Agricultural Policy of the Government of India also encourages the participation in the agricultural technology transfer and assures a move towards a regime of financial sustain ability of extension services through affecting in phased manner, a mere realistic cost-recovery of extension services and inputs, while simultaneously safeguarding the interest of the poor and vulnerable sections. Public extension services are not profit oriented and lacking of sufficient staffs for growing population in our country.

Public and private extension services constitute a new mode of operation in many fields of development, including the development of innovation in developing country agriculture. Private extension is increasingly being emphasized as a mechanism for improving public service provision and implementing development programs. In developing countries, such arrangements are often used to mobilize complementary and scarce resources in the public and private sectors for projects involving the development of infrastructure, communities, and 
agriculture. There are many cases of partnerships among farmers, private companies, government agencies, and nongovernmental organizations (NGOs) under which each entity contributes human, physical, and financial resources to foster the generation and diffusion of innovations, new forms of technologies, and knowledge to redress gaps in the development, production, processing, and marketing of improved agricultural products.

\section{Methodology}

The study was conducted in three taluks of Chitradurga district viz; Challakere, Chitradurga and Hiriyur considering the area and production of Pomegranate in the district. The 60 farmers who are under public extension service and 60 farmers who are in private extension services were selected as sample for the study. Out of 60 farmers 20 growers from each taluk were selected randomly in both the systems of the extension service. Thus the total sample size constituted was 120. Expost facto Research design was employed in the study (Kerlinger, 2010) ${ }^{[2]}$. Data were collected by using pre-tested structured interview schedule through personal interview method. The appropriate statistical tools like mean, frequency, percentage and standard deviation were used for analysis of collected data and to know the adoption level and income level, personal socio-psychological characteristics of pomegranate growers under public and private extension services, Z-test to know the differences in performance of pomegranate growers under public and private extension services and correlation to find out the relationship between the personal, socio- psychological characteristics with performance were employed.

\section{Results and Discussion}

The difference in performance of pomegranate growers under public and private extension services was assessed with the indicators as adoption, income, cost of cultivation and B: C ratio.

Differences in adoption of improved practices by pomegranate growers under public and private extension services

Table 1 revealed that $Z$ value 3.64 shows the significant differences in adoption of recommended practices between pomegranate growers under the public and private extension services. It means private extension services is more contributing towards the adoption of technologies related to pomegranate cultivation than compare to public extension services. It is needless to say that the private extension is specialized services provided to the pomegranate cultivation with all the recommended technologies which boost the yield and in turn the income. Further, input support system extended by the private extension system to the clients in time in required quantity may also influenced the farmers to adopt all the technologies which are essential for increasing yield. Hence, there is a significant difference in adoption level of farmers of public and private extension services system. The findings are in agreement with the results of the study conducted by Shanbogha $(2016)^{[4]}$.

Table 1: Differences in adoption of improved practices by pomegranate growers under public and private extension services $n=120$

\begin{tabular}{|c|c|c|c|c|c|}
\hline \multirow{3}{*}{ Adoption level } & \multicolumn{2}{|c|}{ Public extension service users (n1=60) } & Private extension service users (n2=60) & Z Value \\
\cline { 2 - 5 } & Mean & SD & Mean & SD & \\
\cline { 2 - 5 } & 50.84 & 7.24 & 63.38 & 7.91 & $3.64 *$ \\
\hline
\end{tabular}

* indicates $5 \%$ level of significance

\section{Differences in income of pomegranate growers under public and private extension services}

Table 2 revealed that $\mathrm{Z}$ value 4.78 shows the significant differences in income between the respondents under the public and private extension services, it means private extension services contributes more towards the increasing income than to public extension services. This may be attributed to the fact that the private extension is a paid service offered by the consultant and it is his responsibility to offer the bunch of technologies for adoption and in turn to get good income. Where as in public extension, the extension worker has to cater to the needs of the growers of different category with different cropping systems. The shortage of extension personnel may not be able to give personal attention to every grower. Private extension service system insists the pomegranate growers to adopt all the recommended practices by them. The findings are in agreement with the results of the study conducted by Shanbogha (2016) ${ }^{[4]}$.

Table 2: Differences in income of pomegranate growers under public and private extension services $n=120$

\begin{tabular}{|c|c|c|c|c|c|}
\hline \multirow{3}{*}{ Income level } & \multicolumn{2}{|l|}{ Public extension service users (n1=60) } & Private extension service users (n2=60) & Z Value \\
\cline { 2 - 5 } & Mean & SD & Mean & SD & \multirow{2}{*}{$4.78 *$} \\
\cline { 2 - 5 } & 239301.35 & 19830.76 & 347548.65 & 17549.5 & \\
\hline
\end{tabular}

* indicates $5 \%$ level of significance

\section{Overall adoption level of pomegranate growers under} public and private extension service $n=120$

Figure 1 indicates the overall adoption level of pomegranate growers under public and private extension services. Majority $(40 \%)$ of the pomegranate growers who had public extension service belonged to medium adoption category and the pomegranate growers who had private extension services belonged to high (40\%) adoption category.

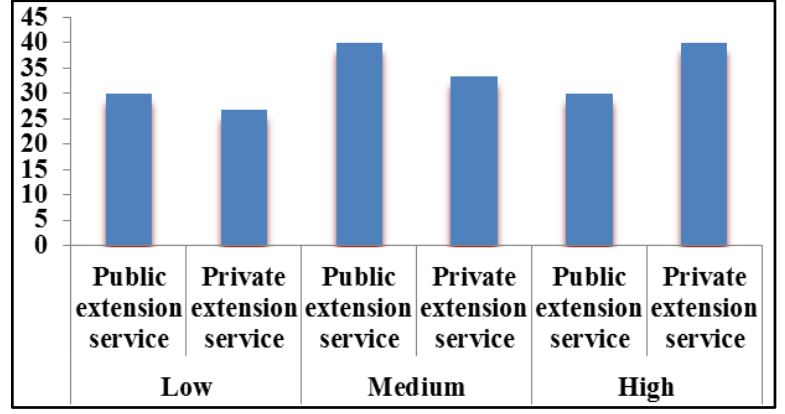

Fig 1: Overall adoption level of pomegranate growers under public and private extension service 
Cost of cultivation and benefit Cost ratio of pomegranate growers under public and private Extension services $\mathbf{n}=$ 120

Table 3 revealed that cost of cultivation and $\mathrm{B}$ : $\mathrm{C}$ ratio of pomegranate growers using public and private extension services. The highest B: C ratio was possessed by Hiriyuru taluk (3.05) followed by Challakere (2.81) and Chitradurga (2.75). With regard to public extension service $\mathrm{B}$ : $\mathrm{C}$ ratio was 2.811. Table 11 also revealed that cost of cultivation and $B: C$ ratio of pomegranate growers using private extension services, the highest $\mathrm{B}: \mathrm{C}$ ratio was possessed by Challakere (3.47) followed by Hiriyur (3.44) and Chitradurga (3.30). With respect to pooled data, 3.40 benefit cost ratio was found with respect to growers using private extension service compared to growers using public extension service (2.81).

The B: C ratio of private extension to public extension services is more because of the reasons that the private extension being a specialized paid service offered by the consultant need to assure higher income compared to public extension service. Further, the adoption of the technologies in private extension is ensured by the consultant with periodical visits, supervision and monitoring of the status of the crop in each stage. The preventive measures taken by the consultants in pest and disease management might have also contributed for higher $\mathrm{B}$ : $\mathrm{C}$ ratio than public extension services. The above mentions findings were in conformity of Shanbhogha $(2016)^{[4]}$.

Hiriyuru had highest B: C ratio that is 3.05 under public extension services because major public agency such as KVK is functioning in this taluk, so they organize frequent training programmes related to pomegranate cultivation. The findings are in agreement with the results of the study conducted by Shanbogha $(2016)^{[4]}$.

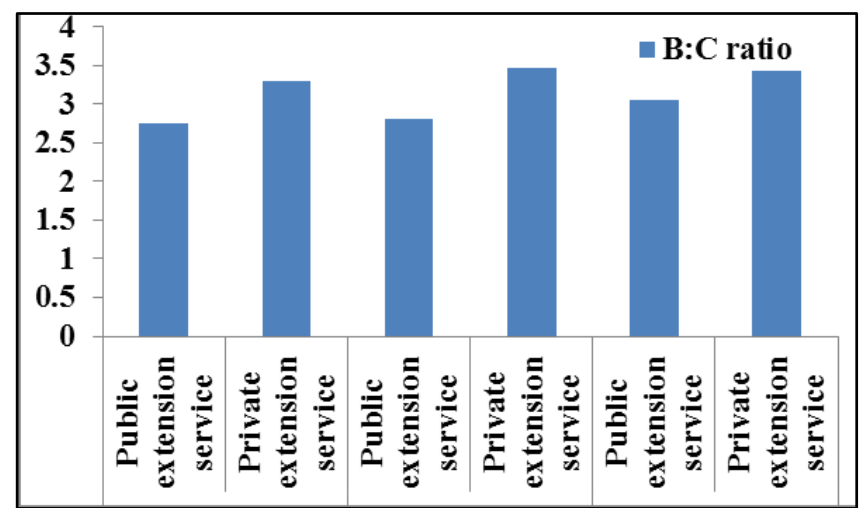

Fig 2: Benefit Cost ratio of pomegranate growers under public and extension services

Table 3: Cost of cultivation and benefit Cost ratio of pomegranate growers under public and private extension services. $n=120$ (Per acre)

\begin{tabular}{|c|c|c|c|c|c|c|}
\hline Taluks & Extension agency & Total Returns & Total Cost & Net returns & B:C ratio & Difference in B:Cratio \\
\hline \multirow{2}{*}{ Chitradurga $(n=40)$} & Public extension service & 354935.05 & 128709.40 & 226225.65 & 2.75 & \multirow{2}{*}{0.55} \\
\hline & Private extension service & 473664.95 & 143444.40 & 330220.00 & 3.30 & \\
\hline \multirow{2}{*}{ Challakere $(n=40)$} & Public extension service & 358329.35 & 127438.80 & 239301.00 & 2.81 & \multirow{2}{*}{0.66} \\
\hline & Private extension service & 502105.15 & 144695.85 & 357409.30 & 3.47 & \\
\hline \multirow{2}{*}{ Hiriyuru $(n=40)$} & Public extension service & 387777.05 & 126987.70 & 260789.35 & 3.05 & \multirow{2}{*}{0.39} \\
\hline & Private extension service & 500014.30 & 145000.20 & 355014.10 & 3.44 & \\
\hline \multirow{2}{*}{ Pooled $(n=120)$} & Public extension service & 367017.81 & 127711.96 & 242105.33 & 2.81 & \multirow{2}{*}{0.59} \\
\hline & Private extension service & 491928.13 & 144380.15 & 348346.20 & 3.40 & \\
\hline
\end{tabular}

\section{Conclusion}

The adoption of the recommended practices by private extension system is better compared to public extension system which implies that the continuous guidance by the extension worker would enhance the adoption of practices. The Public extension needs to be engaged in establishing good rapport with the farmers and to promote the technologies. The income of the pomegranate growers under private extension system is much better than the public extension system and it clearly implies the adoption of technologies as recommended either by public or private extension would really enhance the income from the pomegranate farmers. There is a need to persuade and make the farmers of public extension to adopt the technologies in totality which would realize the better income.

\section{References}

1. Anchule MM. A study on production technology of exportable grape used by growers. M.Sc. (Agri.) thesis (UNPUB.) Marathwada Agricultural University, Parbhani, 1996.

2. Angadi SC. A study on knowledge, adoption and marketing pattern of pomegranate growers in Bagalkot district in Karnataka state. M.Sc. (Agri.) Thesis (UNPUB.), Univ. Agric. Sci., Dharwad, 1999.

3. Kerlinger FN. Foundations of behavioral research, Surjeet publications, New Delhi, 2010.
4. Shanabhoga MB. Study on impact of public and private agriculture extension on production and income of pomegranate growers in Chitra Durga. M.Sc. (Agri.) Thesis (UNPUB.), Univ. Agric. Sci., Bangalore, Karnataka, 2016. 